\title{
JoHn DEWEY AND THE MIND-BODY Problem in the Context: The Case of «NEUTRAL MONISM»
}

\begin{abstract}
A. Leonov
Abstract. The main focus of this paper is the mind-body problem in its relation to the doctrine of 'neutral monism' and the question who can be considered its proponents. According to Bertrand Russell, these are Ernst Mach, William James, and John Dewey (to name a few). This paper aims to clarify whether Russell himself was right in his conclusions or not. At first, I start with the clarification of the relation between 'neutral monism' and 'dual-aspect theory'. Secondly, I analyze the 'big three' of the neutral monism: Mach, James and Russell. My starting-point here is Russell's very understanding of Mach and James positions. In the end, it appears that neither Mach, nor James as well as Dewey can be considered as neutral monists. It was rather Russell's misunderstanding of the both James' radical empiricism and Mach's analysis of sensations, which led him to the creation of his own original version of 'neutral monism' (or 'Russelian monism').
\end{abstract}

Keywords: mind-body problem, neutral monism, dual-aspect theory, Russell, Mach, James, Dewey.

To explain is to employ one thing to elucidate, clear, shed light upon, put in better order, because in wider context, another thing [5, p. 232].

\section{Introduction}

The mind-body problem is a problem of the relation of the mind to the body: how is that possible that immaterial mind interacts with the material body? And do they really interact? And what is the mind as versus the body? These are the age-long questions, which struck minds of 
many philosophers throughout the centuries. Traditionally, the mind-body problem and its clear articulation are referenced to Rene Descartes, who, in his magnum opus «Meditations of the First Philosophy» addressed this problem directly.

Descartes' decision of how to treat this problem is traditionally called dualism, or, if to be more precise, the substance dualism: Descartes thought of mind and body as substances, which cannot interact with each other directly, but which, nevertheless, form the union of the mind and body through the 'pineal gland'. That being said, Descartes was intuitively trying to show that we cannot explain mental things from physical things, which in the contemporary philosophy of mind is called the knowledge argument: an intuition that one cannot get mental descriptions through the physical descriptions only $[8]^{1}$. Baruch Spinoza, in his Ethics, was trying to overcome the Cartesian substance dualism and proposed that there was only one substance, namely, God or Nature, and mind and body were just two aspects (or attributes) of this substance. In the contemporary philosophy of mind, this theory is called the 'double-aspect theory'2

${ }^{1}$ According to the classical argument, there is a brilliant scientist, Mary, who knows everything about colors, but lives in the black-and-white room. While she knows everything about colors scientifically, she never saw a single color herself. So, what will happen when it comes the day for her to really see, say, some red tomato, for the first time? Will she wonder like: «Oh, so that's how it looks like!», or she would say something like «I knew it to be precisely like this!».

According to the non-reductionist interpretation of the argument, and if to speak in the terms of James and Dewey's crucial distinction between the primary experience and the secondary experience, Mary, while still being in a black-and-white room, is not able to understand what it is like to see a red tomato from the point of view of the primary experience (a simple qualitative that), which in Analytic notions is called as what-it-is-likeness (there is something it is like to be a conscious organism, having some qualitative character (qualia)).

Physicalist attacks on this argument can be reduced to the statement that all Mary's 'knowledge' is enough to understand in terms of the secondary experience (i.e., purely reflective and scientific knowledge) only. Physicalists simply reduce the primary experience level to the secondary one, as opposed to the non-reductionists, arguments of whom put a strong accent on that before the things are really known reflectively, they are 'known' qualitatively. Or, if to express it in Dewey's fashion, «things are had, before they are known».

${ }^{2}$ I think, Spinoza's understanding was closer (from the epistemological point of view) to the double-aspect theory: we, as human beings, can epistemologically grasp only two attributes (or aspects) of God or Nature, i.e., mental and physical. But, in that God is «a being absolutely infinite» [1, p. 85], it doesn't mean we have to be restricted to these two (from the ontological standpoint). For example, in his 1974 famous paper «What is it like to be a bat?» [18] Thomas Nagel argued that we don't actually know what it is like to be a bat. The latter possesses sonar. We don't. Thus, we just don't know how bat is processing information in order to survive in the environment and, of course, 
According to Bertrand Russell, John Dewey was one of the prominent representatives of the philosophical doctrine called 'neutral monism'. In his «An Outline of Philosophy» Russell writes the following:

Popular metaphysics divides the known world into mind and matter, and a human being into soul and body. Some - the materialists - have said that matter alone is real and mind is an illusion. Many - the idealists in the technical sense, or mentalists, as Dr. Broad more appropriately calls them - have taken the opposite view, that mind alone is real and matter is an illusion. The view which I have suggested is that both mind and matter are structures composed of a more primitive stuff which is neither mental nor material. This view, called 'neutral monism', is suggested in Mach's «Analysis of Sensations», developed in William James's Essays in Radical Empiricism, and advocated by John Dewey, as well as by Professor R.B. Perry and other American realists. The use of the word 'neutral' in this way is due to Dr. H.M. Sheffer, of Harvard, who is one of the ablest logicians of our time [21, p. 303].

So, according to Russell, John Dewey was one of the main proponents of the 'neutral monism'. But Russell is not the one who understands Dewey's ontology in this way. The same conclusion was, for example, recently made by the contemporary philosopher Peter Godfrey-Smith, in his review of Dewey's magnum opus «Experience and Nature»:

Dewey chooses the term 'emergentist' for his view of the mind, though it might be better to see this as a version of neutral monism, and a more genuinely 'neutral' one than some other views described with that term. Nature's activities are not grounded in the physical any more than in the mental. What we call the 'physical' or 'material' is part of what goes on; what we call the 'mental' is another part [7, p. 5-6].

But, if, for example, to read the article on «Stanford Encyclopedia of Philosophy» on this topic [23], one can find no reference to Dewey as one of the advocates of this theory at all. Thus, I think, there is a need of the investigation in order to clarify Dewey's relation towards this theory too. In order to do this, I will briefly overview the positions of the 'big three' of the neutral monism: Ernst Mach, William James, and Bertrand Russell (in case of the latter, I will constrain my description only with his understanding of what the very neutral monism is regarding the other two of the 'big three'). (According to Studenberg, «only Russell uses the label 'neutral monism'. But there is a widespread agreement that Mach, James,

we don't know what it's like for it to process information from the phenomenal (or phenomenological) point of view. We just have no epistemological access to its realm. But nevertheless, it can surely mean that bat's experience can go beyond what we now consider as 'mental' or 'physical' altogether. 
and Russell are the three most important philosophers in this tradition» [23]. Whether it is the case, we have to find out.)

But, at first, let's begin with the definitions. Here, I think, there is a strong need to distinguish between the 'neutral monism' and the 'doubleaspect theory'. Though, «the decision about these types of theorywhether they are incompatible rivals, whether they are distinct but compatible, or whether they are identical - is still out» [23] and although, they are mixed up and conflated ${ }^{3}$, we still have to try to keep the strong and clear difference. Given that, one has to provide a clear reasoning in order to eliminate the confusion between these philosophical enterprises.

On my understanding, neutral monism means that there is one common reality, which, itself, is 'neutral', but which has two levels or properties, e.g., mental and physical, which are not reducible to this reality and the very neutral reality cannot be explained through these non-neutral features of it. So, these non-neutral features are, in a way, the products of the neutral reality. «Grouped one way, the neutral entities that constitute your brain are thoughts and feelings; grouped another way, they are atoms and neurons and lobes» [23]. But, «the intrinsic nature of ultimate reality is neither mental nor physical» [Ibid.]. And the very idea of neutrality is as follows: «being intrinsically neither mental nor physical in nature ultimate reality is said to be neutral between the two» [Ibid.].

Dual-aspect theory, on the other hand, is a theory which says that there is one reality, but which is both mental and physical simultaneously, and the conceiving of its 'mentality' or 'physicality' follows from the very perspectives we are addressing this reality ${ }^{4}$. A very good example of dualaspect theory is presented by Spinoza in his Ethics. For Spinoza, there is only one substance, which he calls God or Nature, which has an infinite number of attributes (or aspects), of which, we can grasp only two: mind and matter. So, God is simultaneously mind and matter altogether. That's

\footnotetext{
${ }^{3}$ For example, Stephen Priest, in his book 1991 «Theories of the Mind», in the chapter titled «Double Aspect Theory» [19, p. 150-182] writes about Spinoza as both the originator of double-aspect theory and as well Russell's neutral monism. In general, Priest does not distinguish between two approaches.

${ }^{4}$ In this sense, I disagree with Studenberg's definition of both doctrines. According to him, «neutral monism and the dual-aspect theory share a central claim: there is an underlying reality that is neither mental nor physical. But that is where the agreement stops» [23]. I think that this is direct definition of neutral monism, but not of the dualaspect theory, because, if to accept such definition, there is no room for panpsychism in case of the dual-aspect theory. Stephen Priest also confuses two theories: «the double aspect theory is the theory that mental and physical are two types of properties of some underlying reality which is intrinsically neither mental nor physical» [19, p. 150].
} 
why, Spinoza is considered as a panpsychist too.

At first, I will briefly explicate Russell's position on 'neutral monism' through his views on the 'predecessors' (Mach, James) and will conclude, whether Russell was right in his conclusions or the label of 'neutral monism' is solely based on his misunderstanding of the philosophers.

Afterwards, I will explicate Dewey's position within this context and find out, whether he can be fit into the list of 'neutral monists' (if there are any) or not.

\section{A Theory of Neutral Monism: A Historical-Comparative Approach}

\subsection{Bertrand Russell}

Bertrand Russell seems to be the first advocate of the label 'neutral monism'5: «of the three, only Russell uses the label 'neutral monism'» [23]. Thus, here, I will briefly describe Russell's understanding of 'neutral monism' as put in his famous 1914 essay on «The Nature of Acquaintance», relating its 'originators' such as James and Mach, as well as in his 1945 «History of The Western Philosophy». Despite the fact that there is a difference in time and positions (in 1914, Russell was an opponent of this theory, and beginning from 1919 - a proponent), as well as he developed his own version of neutral monism, his common interpretation of its historical predecessors (and namely James, who influenced him in this manner) didn't change ${ }^{6}$.

In the essay «On the Nature of Acquaintance» [20], Russell provides the following definition:

'Neutral Monism' - as opposed to idealistic monism and materialistic monism - is the theory that the things commonly regarded as mental and

\footnotetext{
${ }^{5}$ According to Elizabeth Eames, «this term was used by James to name his particular way of circumventing the body-mind problem in philosophy» [2, p. 198]. She appeals to James's 1905 essay «The Notion of Consciousness», which I briefly analyze below.

${ }^{6}$ As mentioned-above, I will omit the discussion of namely Russell's theory of neutral monism, which deserves some special attention in order to be fully described and analyzed, because of its complexity and changes throughout his life (that's why it was even called as 'Russelian monism', instead of just 'neutral'). But nevertheless, one can get some common understanding of Russelian monism in Stephen Priest's book «Theories of the Mind» [19, p.161-170]. (It seems, that for Priest 'neutral monism' and the 'double-aspect theories' are identical, in that he describes Russell's neutral monism in the chapter called 'Double-aspect theories' [19, p. 151-182], where he mainly includes as Spinoza, Russell and Strawson as the main representatives, though, he also mentions David Hume and William James.)
} 
the things regarded as physical do not differ in respect of any intrinsic property possessed by the one set and not by the other, but differ only in respect of arrangement and context [20, p. 139].

For example, the postal directory, «where the same names come twice over»: alphabetical (as, say, mental) and geographical (as, say, physical) orders [Ibid.]. Or, "ideas' of chairs and tables are identical with chairs and tables, but are considered in their mental context, not in the context of physics»[Ibib.]. Therefore, «the whole duality of mind and matter, according to this theory, is a mistake; there is only one kind of stuff out of which the world is made, and this stuff is called mental in one arrangement, physical in the other» [Ibid., p. 140].

(As the originators of this theory, Russell names William James and his «Essays in Radical Empiricism» (especially an essay «Does 'Consciousness' Exist?») as well Ernst Mach and his 1886 book «Analysis of the Sensations», whose theory «seems to be substantially the same as James's» [Ibid.]. Russell thinks that both of them developed this theory independently of each other, and the only difference is that «Mach arrived at his opinions through physics. James, whose opinions are essentially the same, arrived at them through psychology» [Ibid., p. 141] $]^{7}$.)

Although, Russell quotes James's mentioned-above essay in that «there is no aboriginal stuff or quality of being, contrasted with that of which material objects are made, out of which our thoughts of them are made; but there is a function of experience» [Ibid., p. 140, italics added]; as well as the main James's thesis that «there is only one primal stuff or material in the world, a stuff of which everything is composed», which is itself a 'pure experience' [Ibid., p. 141, italics added], Russell, from the very beginning, emphatically puts the primary accent namely on that «stuff out of which the world is made» [Ibid., p. 140], rather than that very 'stuff' is nothing but 'pure experience'. In my opinion, namely this was the wrong path for the interpreting of James's radical empiricism, and what already made James's 'stuff' as something ultimate and 'neutral', while 'pure experience' as something superfluous, derivative and which can be changed. (Later on, in this essay, he's critiquing James's usage of experience from the idealistic standpoint [Ibid., p. 145].)

Namely the same description of James's radical empiricism as 'neutral monism' was developed in Russell's «History of Western Philosophy» [22, p. 811-814]. Again, he cites James's 1904 essay «Does 'Consciousness' Exist?»: «no aboriginal stuff or quality of being, contrasted with that of which

\footnotetext{
${ }^{7} \mathrm{He}$ also includes Ralph Barton Perry as the advocate of the same theory [20, p. 140].
} 
material objects are made, out of which our thoughts of them are made» [22, p. 812]. And that there is "'only one primal stuff or material' out of which everything in the world is composed», and which James called 'pure experience' ( «as the immediate flux of life which furnishes the material to our later reflection») [Ibid., p. 813]. But again, Russell emphatically points to the 'stuff' rather than experience, as the main notion of James's radical empiricism:

It will be seen that this doctrine abolishes the distinction between mind and matter, if regarded as a distinction between two different kinds of what James calls 'stuff'. Accordingly, those who agree with James in this matter advocate what they call 'neutral monism', according to which the material of which the world is constructed is neither mind nor matter, but something anterior to both. James himself did not develop this implication of his theory; on the contrary, his use of the phrase 'pure experience' points to a perhaps unconscious Berkeleian idealism [Ibid., p. 814].

Russell continues to critique the notion of experience, until he concludes:

On common-sense grounds, therefore, we shall say that 'experience' is not coextensive with the 'stuff' of the world. I do not myself see any valid reason for departing from common sense on this point. Except in this matter of 'experience', I find myself in agreement with James's radical empiricism [Ibid.].

On what it will be shown below, one can see that for James it's impossible to divide between 'stuff' and 'experience', because the former is the latter. They are identical.

\subsection{Ernst Mach}

Ernst Mach's view on 'neutral monism' was explicated in his «Analysis of Sensations» (1886). It is thought, Mach influenced James's view on radical empiricism, as well as Russell's neutral monism ${ }^{8}$. Also, Mach is considered to be the first of the 'big three' of the neutral monists. Thus, I have to say a few words about his philosophical enterprise relating neutral monism.

Mach's ontology was considered largely through emphasis of 'sensations', which some understand as a solipsistic move [16, p. 1]. I, myself, do not think it is the case. On my understanding, we have to start from the different perspective, namely, experience. For Mach, experience is divided into elements, namely (1) A, B, C . ; (2) K, L, M ..; and (3) $\alpha, \beta, \gamma \ldots$.

${ }^{8}$ According to Studenberg, «Ernst Mach (1838-1916) occupies a central position in the history of neutral monism. He influenced William James and Bertrand Russell and, through them, all of the writers on neutral monism in the English speaking world» [23]. 
(1) The A, B, C . ., cluster stands for the complexes of colors, sounds etc., which we call bodies or 'the world of matter' [14, p. 8-9; 14-15];

(2) The K, L, M ...; cluster stands for own body [Ibid., p. 9];

(3) And finally, the $\alpha, \beta, \gamma \ldots$; one denotes «the complex composed of volitions, memory-images, and the rest», that is our mentality or psyche [Ibid.].

Mach thinks of these elements as of the better substitutes of notions like 'body' and 'ego', which «are only for provisional orientation and for definite practical ends» [Ibid., p.13] in order to deal with our experience properly and to eliminate the antithesis between 'world', 'ego', 'sensation', 'thing', 'body and spirit' vanishes.

The main idea of the book is to show that there is «no real gulf between the physical and the psychical» [Ibid., p.71], all this very gulf is just the result of «our habitual stereotyped conceptions» [Ibid., p. 17]. The psychical and physical are just functional relations between the elements. For example, one of the main notions used by Mach in the book, sensations, simply means out psychological ${ }^{9}$ relation of our body $(\mathrm{K}, \mathrm{L}, \mathrm{M} \ldots$...) to the world (A, B, C ...). The world itself $(\mathrm{A}, \mathrm{B}, \mathrm{C} \ldots)$ is a not sensation. It is the latter only in its particular functional relation to the body: «The elements A, B, C ..., therefore, are not only connected with one another, but also with K, L, M. To this extent, and to this extent only, do we call A, B, C...sensations, and regard A, B, C as belonging to the ego» [Ibid., p. 16].

At the same time, in other functional relation, these elements are what we call 'physical objects'. And Mach calls them 'sensations', because most of people are used to perceive them as sensations (colors, sounds etc.) [Ibid.]. And here, «the gap between what bodies and sensations [...], what is without and what is within, between the material world and the spiritual world» vanishes, in that «all elements A, B, C . ., K, L, M ..., constitute a single coherent mass, when any one element is disturbed, all is put in motion» [Ibid., p. 17].

For us, everything (e.g., perceptions, presentations, volitions, and emotions) «the whole inner and outer world» is composed of the «combinations of varying evanescence and permanence, out of a small number of homogeneous elements»[Ibid., p.22]. «The primary fact is not the ego,

\footnotetext{
${ }^{9}$ One could even say phenomenological.
} 
but the elements (sensations)» ${ }^{10}$. $\ll$ The elements constitute the I» [Ibid., p. 23].

Thus, there is «no opposition of physical and psychical, but simple identity as regards these elements. In the sensory sphere of my consciousness everything is at once physical and psychical» ${ }^{11}$ [Ibid., p. 44].

For Mach «the elements A, B, C ... are immediately and indubitably given [...]» [Ibid., p. 45]. But how are they given? Phenomenologically speaking, the world is given through sensations in their two-fold functional meaning:

(1) Sensations as the result of the interconnection of one's body (K, L, $\mathrm{M} \ldots$...) with the world (A, B, C ...);

(2) The very world (as physical object) perceived as the sensation in its common-sense usage (colors, sounds, shapes etc.).

According to Mach, the guiding principle for studying sensations is the «principle of the complete parallelism of the psychical and physical» [Ibid., p.60]. Mach wants to emphasize, that his view is not identical to the «conception of the physical and psychical as two different aspects of one and the same reality» [Ibid., p. 61 $]^{12}$.

\footnotetext{
${ }^{10}$ Which are given to us as sensations in that functional and common sense as mentioned-above.

${ }^{11}$ On the pages $44-45$, one can see that Mach clearly identify sensations with the field of psychology. But nevertheless, one can also see that simultaneously Mach treats sensations in the phenomenological sense, namely, as the primary givenness of our experience.

${ }^{12}$ On the pages 57-60 of his book, Mach introduces two principles, namely the principle of continuity and the principle of sufficient determination or sufficient differentiation. These principles were developed by our intellect through adaptation and habit. Simply put, the first one means «Wherever A appears, B is added in thought» $[14$, p.57]. The second principle means roughly the principle of association and determination: when $\mathrm{A}$ appears, it must be associated with $\mathrm{B}$, or in this sense, A determines B.

Thus, «the two things A and B being conceived as connected that to every change of the one that can be observed at any moment there corresponds an appropriate change of the other. It may happen that both $\mathrm{A}$ and $\mathrm{B}$ are conceived as complexes of components, and that to every component of A a particular component of B corresponds»[Ibid., p. 58]. Mach goes on: «it is evident that the principle of continuity and that of sufficient determination can be satisfied only on the condition [italics added] that with the same $\mathrm{B}$ (this or that sensation) we always associate the same $\mathrm{N}$ (the same nerve-process) and discover for every observable change of $\mathrm{B}$ a corresponding change of $\mathrm{N}$. [...] In a word, for all psychically observable details of B we have to seek the correlated physical details of N» [Ibid., p. 59]. Even when the hallucination is present, some certain nervous process as the «essential and immediate condition of the sensation» must be the case.
} 
In the first place, our view has no metaphysical background, but corresponds only to the generalized expression of experiences [italics added]. Again, we refuse to distinguish two different aspects of an unknown tertium quid; the elements given in experience, whose connexion we are investigating, are always the same, and are of only one nature, though they appear, according to the nature of the connexion, at one moment as physical and at another as psychical elements [Ibid., p. 61].

Thus, the 'sensationalism' of Mach is based on the 'generalized expression of experiences'. Here, there is no place for the third 'neutral' common reality, which gives rise to psychical and physical. The latter are the manifestations of the very experience as given in sensations ${ }^{13}$. Is there any place for 'neutrality' in Mach's ontological picture? Yes, there is. The world itself $(\mathrm{A}, \mathrm{B}, \mathrm{C} \ldots$...) in its «all forms, colors, etc., are of like nature in themselves, being in themselves neither psychical nor physical» [Ibid., p. 62].

Thus, the ontological picture of Mach's philosophical doctrine is the following:

(1) Experience, which consists of elements A, B, C ... (the world of matter), $\mathrm{K}, \mathrm{L}, \mathrm{M} \ldots$ (our body), $\alpha, \beta, \gamma \ldots$ (our mentality or psyche), which are homogenous themselves, and phenomenologically are given to us through sensations. The difference between psychical and physical lies in their functional (or perspective) relation to the elements.

(2) The world (A, B, C ...) as in itself is neutral ${ }^{14}$.

But (2) does not entail the common neutral reality, which gives rise to different non-neutral aspects or properties (mental and physical). Thus,

Thus, «we cannot think of this immediate condition as being varied without conceiving of the sensation of being varied, and vice versa» [Ibid., p. 60].

I would say that the 'condition' for the two principles of which Mach is talking about in the above passage, reminds me of what in the Analytic philosophy of mind is be called the notion of supervenience. This notion was introduced by Donald Davidson and it goes like this «mental characteristics are in some sense dependent, or supervenient, on physical characteristics. Such supervenience might be taken to mean that there cannot be two events alike in all physical respects but differing in some mental respect, or that an object cannot alter in some mental respect without altering in some physical respect» [3, p. 214]. Simply put, «there cannot be an A-difference without a B-difference» [15].

According to Jaegwon Kim, supervenience means the following relations: (1) Covariance; (2) Dependence; (3) Nonreducibility [13].

${ }^{13}$ Compare with James: «But this present object, what is it in itself?» Of what stuff is it made? Of the same stuff as the representation. It is made of sensations; it is something perceived. Its esse is percipi, and object and representations are generically homogeneous» [12, p. 264].

${ }^{14}$ As opposed to W. James view, according to whom the world in itself is experiential for itself, which opens the door to the panpsychism (see below). 
Mach is neither a neutral monist, nor a solipsist. If it is a monism, then it is an experience monism, as given in elements (which are phenomenologically perceived as sensations).

\section{$2.3 \quad$ William James}

John Dewey, in his «Nature and Experience», clearly states:

We begin by noting that 'experience' is what James called a doublebarrelled word. [...] It is 'double-barrelled' in that it recognizes in its primary integrity no division between act and material, subject and object, but contains them both in an analyzed totality. 'Thing' and 'thought', as James says in the same connection, are single-barrelled; they refer to products discriminated by reflection out of primary experience $[5$, p. $10-$ $11]$.

Though, in the following footnote, Dewey, himself, says that doesn't intend «to attribute to James precisely the interpretation given in the text» [Ibid., p. 11], from this, it is obvious, that namely William James was the main influence on Dewey's understanding of the notion of experience.

Here, Dewey refers to the very influential essay by James, called «Does 'Consciousness' Exist?»(1904). It was influential not only for Dewey's understanding of experience, but, played a very big role for Bertrand Russell and the formation of his 'neutral monism' as we have seen before. But, this is not the end of the story. James is considered to be one of the 'big three' of the 'neutral monism' theorists [23]. But the main question is the following: is he? Here, I want to show that to consider James as a 'neutral monist' is a big mistake. For this purpose, I will analyze his two 1904 essays, namely «Does 'Consciousness' Exist?», and «A World of Pure Experience» as collected in «Essays in Radical Empiricism» (1912) $[10,11]$.

In his «Does 'Consciousness' Exist?» James introduces the notion of 'radical empiricism', which as according to Leopold Studenberg, is «the view that has become the paradigm of neutral monism» [23]. And if it is such, than the very concept of 'neutral monism' is in a big trouble.

James's main idea in this essay is the following: there is «only one primal stuff or material in the world, a stuff of which everything is composed, and if we call that stuff 'pure experience', then knowing can easily be explained as a particular sort of relation towards one another into which portions of pure experience may enter. The relation itself is a part of pure experience; one its 'terms' becomes the subject or bearer of the knowledge, the knower, the other becomes the object known» [10, p. 4-5]. In this essay, 
James wanted to show that there was no consciousness as a «special stuff or way of being» [Ibid., p. 14] whatsoever. That it is just timeless «witness of happenings in time, in which it plays no part», being just «the logical correlative of 'content' in an Experience of which a peculiarity is that fact comes to light in it, that the awareness of content takes place» $[9$, p. 5]. In this sense, self-consciousness means that when certain contents are taking place, they «are not without witness as they occur» [Ibid.]. The very existence of consciousness is reduced to being just an «epistemological necessity, even if we had no direct evidence of its being there» [Ibid.]. Again, experience is not divided into consciousness and its content, they are fundamentally the same. And it is namely in this context, James presents his «double-barrelled» conception of experience. That is, fundamentally our experience (or as James puts it 'phenomenon', 'datum', 'Vorfindung') is double-aspect, only the definite perspective distinguishes whether it is physical or mental: «does a given undivided portion of experience, taken in one context of associates, play the part of a knower, of a state of mind, of 'consciousness'; while in a different context the same undivided bit of experience plays the part of the thing known, of an objective 'content.' In a word, in one group it figures as a thought, in another group as a thing. And, since it can figure in both groups simultaneously we have every right to speak of it as subjective and objective both at once» [Ibid., p. 7]. Is it a still dualism? Yes, it is. But it is not, as James puts it, 'single-barrelled', or dualism of substances, but double-aspect one. It is dualism of aspects, or perspectives of our experience. It means that one reality is «in two places at once, both in outer space and a person's mind» [Ibid., p. 8]. And, such a dualism «instead of being mysterious and elusive, it becomes verifiable and concrete. It is an affair of relations, it falls outside, not inside, the single experience considered, and can always be particularized and defined» [Ibid.].

Under subjective James understands what «experience represents», on the other hand, objective is what is represented. And they are the same: «no dualism of being represented and representing resides in the experience per se». In pure experience, there is also no division of «consciousness and what consciousness is 'of'. Its subjectivity and objectivity are functional attributes solely, realized only when the experience is 'taken', i.e., talkedof, twice, considered along with its two differing contexts respectively, by a new retrospective experience, of which that whole past complication now forms the fresh content» [Ibid., p. 13].

But, what is the very 'pure experience'? According to James, «for the time being, it is plain, unqualified actuality or existence, a simple 
that»[Ibid.]. The next sentence expresses the very turn: «In this naïve immediacy it is of course valid; it is there, we act upon it; and the doubling of it in retrospection [italics added] into a state of mind and a reality intended thereby, is just one of the acts [italics added]»[Ibid.]. From this, it follows that what we are dealing with directly is this immediacy of stream of experience, only which is afterwards divided into subjective and objective. And this very division is the also the very act. Act of our experience. And he goes on: «the immediate experience in its passing is always 'truth', practical truth, something to act upon, at its own movement» [Ibid.]. The thing that James wants to express here, I would call the 'pragmatic phenomenology'.

In this very essay, James already made an attack on what was later called the 'neutral monism'. On the page 14, he made an improvisational $\mathrm{Q}$ and $\mathrm{A}$, which cleared up the issue, whether the primal stuff, which he called the 'pure experience' is neutral or not. So, here it is:

Q: If experience has not 'conscious' existence, if it be not partly made of 'consciousness', of what then is it made? Matter we know, and thought we know, and conscious content we know, but neutral and simple 'pure experience' is something we know not at all. Say what it consists of - for it must consist of something - or be willing to give it up! [Ibid., p. 14].

A: To this challenge the reply is easy. Although for fluency's sake I myself spoke early in this article of a stuff of pure experience, I have now to say that there is no general stuff of which experience at large is made. There are as many stuffs as there are 'natures' in the things experienced. If you ask what any one bit of pure experience is made of, the answer is always the same: «It is made of that, of just what appears, of space, of intensity, of flatness, brownness, heaviness, or what not. [...] Experience is only a collective name for all these sensible natures, and save for time and space (and, if you like, for 'being') there appears no universal element [italics added] of which all things are made» [Ibid., p. 14-15].

It is also interesting that James did not think of 'mental' and 'physical' as fundamentally heterogeneous. For James, «their relations to time are identical», both have parts, complex and simple, as well as both «can be compared, added and subtracted and arranged in serial orders» [Ibid., p. 15]. And between mental and physical must be strong correlation: «Of every extended object the adequate mental picture must have all the extension of the object itself. The difference between objective and subjective extension is one of relation to a context solely» [Ibid., p. 16]. And, of course, [...] «thoughts in the concrete are made of the same stuff as things are» [Ibid., p. 19], that is experience.

In his next 1904 essay, «A World of Pure Experience», James continues to develop his theory of 'radical empiricism', which he gave rise in 
his previous essay. He confesses, that 'radical empiricism' is not just a philosophical theory, but his weltanschuung [11, p. 22]. «To be radical, an empiricism must neither admit into its constructions any element that is not directly experienced, nor exclude from them any element that is directly experienced» [Ibid.].

This essay helps understand the ontological question of experience. I understand James's ontology of experience in the threefold manner:

(1) The primary ontology. This is the experience in its pure, not reflected state. Simply «plain, unqualified actuality or existence, a simple that» [10, p. 13].

(2) The functional (or pragmatic) ontology. This is an example of the reflected experience, or experience as given in retrospection, when experience is «taken» [Ibid.]. From the point of view of the former the world is as it is experienced. In this sense, it is 'double-barrelled' or that, which has two aspects: mental and physical. Though, the very experience is not limited to these two ${ }^{15}$.

(3) The ontology of the Beyond. For James, «the beyond must of course always in our philosophy be itself of an experiential nature [...] it must be an experience for itself whose relation to other things we translate into the action of molecules, ether-waves, or whatever else the physical symbols may be» [11, p. 43]. James confesses that «this opens the chapter of the relations of radical empiricism to panpsychism [... ]» [Ibid.]. From this, it follows that James's radical empiricism is not of solipsistic nature, but rather of the panpsychistic.

So, that being said, if to put his philosophy into contemporary views, James, locally speaking, is a double-aspect theorist of experience, and to put things globally: a panpsychist. As one can see, the very experience is in no way neutral.

\footnotetext{
${ }^{15}$ While reading the page 39 of «A World of Pure Experience», one can get the impression that the very notion of experience is infinite: «If one and the same experience can figure twice, once in a mental and once in a physical context (as I have tried, in my article on Consciousness, to show that it can), one does not see why it might not figure thrice, or four times, or any number of times, by running into as many different mental contexts, just as the same point, lying at their intersection, can be continued into many different lines. Abolishing any number of contexts would not destroy the experience itself or its other contexts, any more than abolishing some of the point's linear continuations would destroy the others, or destroy the point itself». That passage reminds me the definition of God as given by Spinoza in his Ethics: «By God I understand a being absolutely infinite, that is, a substance consisting of infinity of attributes, of which each one expresses an eternal and infinite essence» [1, p. 85].
} 


\subsection{The Case of Confusion}

Nevertheless, there is some place in James's radical empiricism, which one can find rather confusing, rather than illuminative. In his 1905 essay, «The Notion of Consciousness» [12], James, while talking about his 'primal stuff' writes the following: «let us suppose that primary reality is of a neutral nature, and let us call it by some name also ambiguous, such a phenomenon, datum, or Vorfindung» [Ibid., p. 268]. All this he now calls, using the plural form as 'pure experiences' and proposes to call it monism or 'rudimentary monism'. But simultaneously, he wants us to distinguish it from the classical «the so-called bilateral monism of scientific positivism or that the Spinozists» ${ }^{16}$ [Ibid., p. 268-269].

Again, for James, the difference is that of ontology: classical dualism distinguishes between two independent ontological realms (in case of Descartes) and that of aspects (in case of Spinoza). But for James, the difference between them is «of a FUNCTIONAL order only, and not at all ontological as understood by classical dualism» [Ibid., p. 271].

Can we consider this 'neutrality' of experience as something in-between the 'mental' and the 'physical', which are non-neutral entities? No, I don't think so. For James, experience is mental as well as physical simultaneously. The very difference between the two is being distinguished only in reflection. So, given that, in what sense is experience 'neutral' then? I think, that it is 'neutral' if we are only speaking in terms of 'classical ontology' (i.e., 'experience' is not purely idealistic (mental) and as well not purely materialistic (physical). I think, here one would say it in the tautological way: experience is experience), but it is in no way neutral in terms

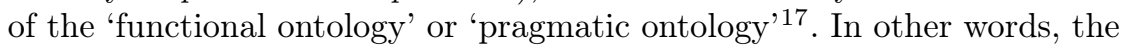
'pure experience' is only neutral to its classical predecessors (idealism and materialism), but it's not neutral to its mental and physical 'barrells', as opposed to the contemporary understanding.

\footnotetext{
${ }^{16}$ Nevertheless, I do not see any fundamental difference between James and Spinoza in this case. If one substitutes Spinoza's 'substance' and 'God' with James's 'primal stuff' and 'pure experience' respectively, one still can get an impression that their ontologies are pretty much the same.

${ }^{17}$ As Eames puts it: «The position is called 'neutral' because, unlike other alternatives to a body-mind dualism, it rejects the monism implicit in idealism, which explains body in terms of mind, and the monism of materialism, which explains mind in terms of body. In this sense, the position is neutral concerning mind and matter. James related his theory to his particular form of 'radical empiricism' and to the leading-on character of experience which is part of his pragmatism» [2, p. 198].
} 


\section{Was John Dewey a Neutral Monist?}

... experience is experience, or is what it is [5, p. 191].

It is obvious that one of the main philosophical influences of Dewey was that of William James and his theory of radical empiricism. Thus, Dewey's 1905 essay «The Postulate of Immediate Empiricism» [4, p. 115] has a goal of clarification of the very notion of experience as postulated by James earlier.

In this essay, Dewey identifies his philosophical position with radical empiricism, pragmatism, humanism as well as introduces his own position named as 'immediate empiricism'. According to Dewey, «Immediate empiricism postulates that things - anything, everything, in the ordinary or non-technical use of the term 'thing' - are what they are experienced as» [Ibid.]. «Things are what they are experienced to be» [Ibid., p. 116].

According to Dewey, the empiricist's position can be understood in terms of 'as' and 'that': «we may express his presupposition by saying that things are what they are experienced as being; or that to a just account of anything is to tell what that thing is experienced to be» [Ibid., p. 117]. Experience itself is always objective and determinate: «if any experience, then a determinate experience; and this determinateness is the only, and is the adequate, principle of control, or 'objectivity'»[Ibid.]. And here, one can already see Dewey's answer against what later would be called 'neutral monism': «it is this thing, and some separate truth, that clamors for its own reform»[Ibid., p. 118]. And it means that there is «no need to search for some aboriginal that to which all successive experiences are attached, and which is undergoing continuous change. Experience is always of thats». Thus, when one is talking about experience, he means neither that there is «some grandiose remote affair that is cast like a net around a succession of fleeting experiences», nor «an indefinite total comprehensive experience which somehow engirdles an endless flux». «Things are what they are experienced to be» and «every experience is some thing» [Ibid.].

Dewey ends his essay with an interesting statement: «I do not mean by immediate experience any aboriginal stuff out of which things are evolved». All he means by it is the descriptive method as employed in natural sciences, but with due respect to the subject investigated [Ibid., p. 119]. This quote, I think, shows what distinguishes Dewey's immediate empiricism from James's radical empiricism. In that, for James, as we have seen, 'pure experience' is the very stuff out of which all the things are evolved (while James denies that there is some general and neutral 'stuff' out which the 
very experience evolves), while for Dewey it is not the case. For the latter, the 'immediate experience' is not such a primary stuff, but a 'descriptive method»'.

As to ontology 'of the Beyond' (if to use James's phrase), Dewey states that «there is nothing in the text that denies the existence of things temporally prior to human experiencing of them». Because, it is «fairly obvious that we experience most of the things as temporally prior to our experiencing of them», but the very essence of Dewey's intention here was to show that «we are not entitled to draw philosophic (as distinct from scientific) conclusions as to the meaning of prior temporal existence till we have ascertained what it is to experience a thing as past» [Ibid., italics added].

I think, when Russell in 1927 mentioned John Dewey among the list of 'neutral monists', he meant his recent, as back to those days, book «Experience and Nature» (1925 edition). Thus, one has to make a short overview of this book written by Dewey, in order to clarify the things in question better (i.e., the mind-body problem and the issue of 'neutral monism' $)^{18}$.

Though, Dewey mentions in the very Introduction that the discussion of the mind-body problem is centered in the VII Chapter of the book [5, p. xiii], I think that the mind-body problem is one of the central topics of the book in general. One can also see that the biggest enemies of Dewey are the philosophers of the rationalist school, such as Descartes and Spinoza, as well as early analytic philosophers, which are all called as 'intellectualists'.

In the very introduction, Dewey already identifies the source of the mind-body problem: «the isolation of nature and experience from each other has rendered the undeniable connection of thought and effectiveness of knowledge and purposive action, with the body, an insoluble mystery»; as well as the solution: «the restoration of continuity» between the former and the latter [Ibid.].

In Chapter 1 Dewey presents his understanding of the notions of experience and his own philosophic method. The latter is called as empirical naturalism, naturalistic empiricism or naturalistic humanism [Ibid., p. 1]. The very essence of the empirical method is that «the things are to be studied on their own account, so as to find out what is revealed when they are experienced» [Ibid., p. 5].

\footnotetext{
${ }^{18} \mathrm{I}$ am using the 1929 edition of «Experience and Nature». According to Dewey, besides the rewriting the first chapter, the other parts of the book were influenced only with «a few minor corrections» [5, p. xiii].
} 
As mentioned before, Dewey employs James's understanding of experience as 'double-barrelled' [Ibid., p. 10]. From the very beginning, Dewey speaks of experience as an emergent natural phenomenon: «no one with an honest respect for scientific conclusions can deny that experience is something that occurs only under highly specialized conditions, such as found in a highly organized creature which in turn requires a specialized environment» [Ibid., p. 3]. And though, he does not consider panpsychism: «there is no evidence that experience occurs everywhere and everywhen» [Ibid.]. For Dewey, it is a surely natural phenomenon: «experience is of as well as in nature. It is not experience which is experienced, but nature stones, plants, animals, diseases, health, temperature, electricity, and so on. Things interacting in certain ways are experience; they are what is experienced. Linked in certain ways with another natural object - the human organism - they are how things are experienced as well. Experience thus reaches down into nature; it has depth» [Ibid., p. 4].

Dewey understands experience in the two-fold manner:

(1) The primary experience «sets the problems and furnishes the first data of reflection which constructs the secondary objects»;

(2) The reflective experience deals with the secondary objects and «explain the primary objects», what itself «enables us to grasp them with understanding, instead of just having sense-contact with them». And that's namely how the «test and verification» of (2) through (1) takes place: i.e., «only by return to things of crude or macroscopic experience - the sun, earth, plants and animals of common, everyday life» [Ibid., p. 7].

But how does the very explanation and understanding occur? For Dewey, it happens through meaning: «when the secondary objects, the refined objects, are employed as a method or road for coming to at» the qualitative objects of the primary experience, «these qualities cease to be isolated details; they get the meaning contained in a whole system of related objects; they are rendered continuous with the rest of nature and take on the import of the things they are now seen to be continued with». This empirical method Dewey calls the denotative method [Ibid., p. 8]. Later on, it will be said: «Meaning is objective as well as universal. [...] it indicates a possible interaction, not a separate singleness» [Ibid., p. 156].

And namely that's where the 'intellectualists' such as Descartes are guilty: while relegating experience to «a secondary and almost accidental place» [Ibid., p. 6], 'intellectualism' «meant the theory that all experiencing 
is a mode of knowing» and that all must be reduced and defined in terms of «refined science as such» [Ibid., p. 21]. And this «goes contrary to the facts of what is primarily experienced. For things are objects to be treated, used, acted upon and with, enjoyed and endured, even more than things to be known. They are things had before they are cognized» [Ibid.]. Thus, a connection and continuity between primary and secondary experience is lost, and the dualism of mind and matter is born.

In Chapter 2, Dewey points out that the very mistake of idealism and materialism is that both of them approach their structures as something static and unchangeable, fixed and absolute, while missing that they are themselves subject to change. Structures themselves are functions, namely the functions and characters of events, and «not something intrinsic and per se» [Ibid., p.62]. According to Dewey, «there is no action without reaction». Whatever influences the changes of other things is itself changes [Ibid., p.63], and if structures of mental or physical would be something fixed, they would be simply out of range of these principles [Ibid., p. 62].

That being said, Dewey critically approaches the notions of mind and matter in their traditional usage: «the vague and mysterious properties assigned to mind and matter, the very conceptions of mind and matter in traditional thought, are ghost walking underground» [Ibid., p. 64]. In order to properly deal with them, we have to understand that «natural events are so complex and varied» that one can treat their characteristics as something really different and opposite. Thus, «nothing but unfamiliarity stands in the way of thinking of both mind and matter as different characters of natural events» [Ibid.].

Nearly at the end of this Chapter, Dewey rejected the double-aspect theory: «the idea that matter and mind are two sides or 'aspects' of the same things, like the convex and the concave in a curve, is literally unthinkable». And (what is crucial for our discussion) the neutral monism as well: «that to which both mind and matter belong is the complex of events that constitute nature. This becomes a tertium quid, incapable of designation, only when mind and matter are taken to static structures instead of functional characters». Because of this, Dewey also suggested that it would be much better to try to use words like mind, consciousness, and matter not as nouns, but as adjectives and adverbs: «conscious and consciously, mental and mentally, material and physically». After this, «we would find many of our problems much simplified» [Ibid., p. 64]. From this it clearly follows, that Dewey is not a neutral monist.

What is the source and the possible solution of the mind-body problem then? According to Dewey, «this entire discussion has but a single point. 
It aims to show that the problems which constitute modern epistemology with its rival materialistic, spiritualistic, dualistic doctrines and rival realistic, idealistic, representational theories; and rival doctrines of relation of mind and matter, occasionalism, pre-established harmony, parallelism, panpsychism, etc., have a single origin in the dogma which denies temporal quality to reality as such» [Ibid., p. 124].

Dewey calls his own view on the mind-body relation as an 'emergent theory of mind' [Ibid., p. 222]. Everything in nature is about interaction, and «there is no isolated occurrence»: «interacting events have tighter and looser ties, which qualify them with certain beginnings and endings, and which mark off them from other fields of interaction» [Ibid.]. Dewey distinguishes three plateaus of such interaction fields:

(1) The first one is physical. «It is the scene of narrower and more external interactions, while qualitatively diversified in itself». Its properties are «those of the mathematical-mechanical system discovered by physics and define matter as a general character» [Ibid.].

(2) This one is about life: «qualitative differences, like those of plant and animal, lower and higher animal forms, are here even more conspicuous». It is the psycho-physical level.

(3) The last plateau is «that of association, communication and participation». It consists of individualities. «It is marked through its diversities, however, by common properties, which define mind and intellect; possession of and response to meanings» [Ibid.].

Thus, «body-mind simply designates an affair with its own properties» [Ibid., p. 232]. It «simply designates what actually takes place when a living body is implicated in situations of discourse, communications and participation. [...] 'body' designates the continued and conserved, the registered and cumulative operation of factors continuous with the rest of nature, inanimate as well as animate; while 'mind' designate the characters and consequences which are differential, indicative of features which emerge [italics added] when 'body' is engaged in a wider, more complex and interdependent situation» [Ibid.].

Generally speaking, Dewey dedicates the whole book to the discussion of the mind-body problem in this or that way. The very discussion is long and complicated, but the very point is the following: in order to really deal with the mind-body problem, one has to begin not from the conclusions (i.e., with already formed metaphysical theories as they are now), but 
from the very premises: «the 'solution' of the problem of mind-body is to be found in a revision of the preliminary assumptions about existence which generate the problem» [Ibid., p. 215, 234] ${ }^{19}$.

\section{Conclusion}

The main goal of this paper was to understand what the concept of 'neutral monism' is and who can be considered as its proponent. The whole meaning of this concept appeared to be really problematic and thus, at first, I had to analyze the doctrines (and the description of neutral monism, in case of Russell (as the creator of the very label)) of the 'neutral monists' before Dewey, in order to give the relevant historical and conceptual context and afterwards, to clarify whether John Dewey himself fits into this list. As it was shown, he does not.

But nevertheless, it also interestingly appeared that neither Ernst Mach, nor William James (two of the 'big three' of neutral monism and its 'creators') cannot be considered as neutral monists as well. It also looks like Bertrand Russell was the only 'neutral monist' among the analyzed philosophers, as well as that, as it seems, it was Russell's misunderstanding of James's radical empiricism or a deliberate putting different accents in the latter's theory that led Russell to creating his own original theory of 'neutral monism' (or it's better to say the 'Russelian monism'). Thus, I think, the next interesting step would be to include into the discussion the very Russelian monism, Ralph Perry's philosophical heritage, as well as that of the New Realists (all of them, as mentioned by Russell are proponents of the 'neutral monism' too).

Also, Dewey's understanding of the mind-body problem and its treatment deserves another thorough investigation. Therefore, another interesting step would be the analysis of this issue only. For now, it is really hard to identify Dewey's own position in this context. I think, he

\footnotetext{
${ }^{19}$ Here, I completely agree with Dewey. I, myself, think that in order to really deal with the mind-body problem as postulated by Descartes, we have to analyze the very means, the very how Descartes came up with his conclusions. And, in my opinion, this Cartesian how is intuition (which can be called Scientia [17]). The same goes for Spinoza (Scientia Intuitiva), and also for the contemporary philosophy of mind discussions: e.g., the knowledge argument, the zombie argument etc. All of them appeal to intuition as the source for their arguments (which are made in the form of the thought experiments), and that's why all of them, can be called Cartesians: not from the point of view of their final metaphysical conclusions, but from the point of the methodology. But the very concept of intuition was not thoroughly analyzed and explicated in this context (i.e., the mind-body problem).
} 
can be classified with different names, but no one will truly characterize him. Thus, I will leave this question open for now ${ }^{20}$.

But nevertheless, one thing here is pretty much obvious, and as such is crucial for the very discussion in question: despite Russell's (1927) and Peter Godfrey-Smith's (2013) mentioning Dewey as a proponent of neutral monism, the latter was not a 'neutral monist' relating the mind-body problem and cannot be considered as such. And namely that is, what I wanted to clarify in this paper.

Acknowledgement. I gratefully acknowledge the Fulbright Graduate Student Program for the financial support while working on this project.

\section{References}

[1] Curley E. A Spinoza Reader. The Ethics and Other Works. Benedict de Spinoza. - Princeton, N.J. : Princeton University Press, 1994.

[2] Eames E.R. Bertrand Russell's Dialogue with His Contemporaries. Carbondale and Edwardsville: Southern Illinois University Press, 1989.

[3] Davidson D. Mental Events // Davidson D. (ed.). Essays on Actions and Events. - Oxford : Clarendon Press, 1980. - P. 207-225.

[4] Dewey J. The Postulate of Immediate Empiricism // Hickman L.A., Alexander T.M. The Essential Dewey.-Bloomington and Indianapolis: Indiana University Press, 1998. - Vol. 1. Pragmatism, Education, Democracy. - P. 115-120.

[5] Dewey J. Experience and Nature. - La Salle, Illinois : The Open Court Publishing, 1971.

${ }^{20}$ Maybe, Dewey as an 'emergentist' will fit the best of all. But one has to be cautious here too, because, as according to Dewey, the levels of interactions which give rise to the emergence of mind from the body are «categories of description, conceptions required to state the fact in question. They are not 'explanatory' categories, as explanation is sometimes understood; they do not designate, that is, the operation of forces as 'causes'. They stick to empirical facts noting and denoting characteristic qualities and consequences peculiar to various levels of interaction» [5, p. 223]. From this, one can also see that Dewey's naturalistic empiricism of 1929 can be considered as a direct continuation of his immediate empiricism of 1905, that is, as a descriptive method. 
[6] Hickman L.A., Alexander T.M. The Essential Dewey. - Bloomington and Indianapolis : Indiana University Press, 1998. - Vol. 1. Pragmatism, Education, Democracy.

[7] Godfrey-Smith P. John Dewey's Experience and Nature // Topoi. An International Review of Philosophy. - 2013. - November. [Electronic source]. - Available at: http://petergodfreysmith.com/wpcontent/uploads/2013/06/PGS-on-Experience-and-Nature-Topoi2013.pdf

[8] Jackson F. Epiphenomenal Qualia // The Philosophical Quarterly. 1982. - Vol. 32, No. 127. - P. 127-136.

[9] James W. Essays in Radical Empiricism. - Cambridge, Massachusetts and London: Harvard University Press, 1976.

[10] James W. Does 'Consciousness' Exist? // James W. Essays in Radical Empiricism. - Cambridge, Massachusetts and London: Harvard University Press, 1976. - P. 6-18.

[11] James W. A World of Pure Experience // James W. Essays in Radical Empiricism. - Cambridge, Massachusetts and London: Harvard University Press, 1976. - P. 19-36.

[12] James W. La Notion de Conscience: Translation // James W. Essays in Radical Empiricism. - Cambridge, Massachusetts and London: Harvard University Press, 1976. - P. 81-89.

[13] Kim J. Supervenience as a Philosophical Concept // Kim J. Supervenience and Mind: Selected Philosophical Essays. - Cambridge : Cambridge University Press, 1993. - P. 131-160.

[14] Mach E. Analysis of Sensations, and the Relation of the Psychical to the Physical. - New York : Dover Publications, Inc., 1959.

[15] McLaughlin B. Supervenience. Stanford Encyclopedia of Philosophy. [Electronic source]. - Available at: https://plato.stanford.edu/entries/supervenience/

[16] McNulty M. James, Mach, and the Problem of Other Minds // Transactions of the Charles S. Peirce Society. - 1982. - Vol. 18, No. 3.- P. 244-254. 
[17] Mursell J.L. The Function of Intuition in Descartes' Philosophy of Science // The Philosophical Review. - 1919. - Vol. 28, No.4. - P. 391409.

[18] Nagel T. What is it like to be a bat? // Philosophical Review.1974. - № 83. - P. 435-456.

[19] Priest St. The Theories of Mind.-Boston: Houghton Mifflin Company, 1991.

[20] Russell B. On the Nature of Acquaintance // Russell B. Logic and Knowledge. - New York: Capricorn Books Edition, 1971.-P. 127174.

[21] Russell B. An Outline of Philosophy. - New York: W.W. Norton \& Company, 1961.

[22] Russell B. A History of Western Philosophy and Its Connections with Political and Social Circumstances from the Earliest Times to the Present Day. - New York: Simon and Schuster, 1963.

[23] Studenberg L. Neutral Monism. Stanford Encyclopedia of Philosophy [Electronic source]. - Available at: https://plato.stanford.edu/entries/neutral-monism/

Надійшла до редакиї 12 вересня 2018 р. 


\section{Джон Дьюї та психофізична проблема: на прикладі доктрини «нейтрального монізму»}

Анотація. Головним фокусом статті є психофізична проблема на прикладі доктрини 'нейтрального монізму', а також, прояснення питання, хто може вважатися $\dddot{1} і$ пропонентами. Згідно з Бертраном Расселом, такими є Ернст Max, Вільям Джеймс та Джон Дьюї (серед інших). Стаття намагається прояснити, чи сам Рассел був правий у своїх висновках чи ні. Спершу, я прояснюю відношення між 'нейтральним монізмом' та 'двох-аспектною теорією'. По друге, я аналізую 'велику трійку' нейтрального монізму: Мах, Джеймс, Рассел. Моєю стартовою позицією є саме розуміння Расселом позицій Маха та Джеймса. Наостанок, виявляється, що ані Мах, Джеймс чи Дьюї не можуть розглядатися як нейтральні моністи. Радше, нерозуміння Расселом як радикального емпіризму Джеймса, так і аналізу відчуттів Маха спонукало його до створення власної оригінальної версії 'нейтрального монізму' (чи 'монізму Рассела').

Ключові слова: психофізична проблема, нейтральний монізм, двохаспектна теорія, Рассел, Мах, Дьюї.

\section{Леонов Андрій Юрійович}

Кафедра філософії

Університет Південного Іллінойсу

м. Карбондейл, штат Іллінойс, США

\section{Leonov Andrii}

Department of Philosophy

Southern Illinois University

Carbondale, Illinois, USA

iD https://orcid.org/0000-0002-4174-9734

andriy.leonov90@gmail.com

doi 10.31812 /apd.v0i19.2078 